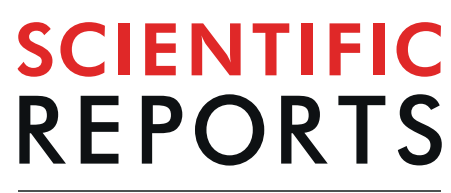

natureresearch

Check for updates

\title{
Synergistic effect of graphene oxide and zoledronic acid for osteoporosis and cancer treatment
}

\begin{abstract}
Gökçen Boran ${ }^{1}$, Sepideh Tavakoli ${ }^{1,2}$, Ingo Dierking ${ }^{3}$, Ali Reza Kamali ${ }^{4}$ \& Duygu Ege ${ }^{1 凶}$
Zoledronic acid (ZOL) is a third generation bisphosphonate which can be used as a drug for the treatment of osteoporosis and metastasis. In this study, graphene oxide (GO) is conjugated with ZOL, and the nanostructured material is evaluated in terms viability, proliferation and differentiation. Furthermore, the associated morphological changes of bone marrow-derived mesenchymal stem cells (BM-MSC), and Michigan Cancer Foundation-7 (MCF-7) breast cancer cells, as well as the effect of the drugs on mineralization of BM-MSCs are investigated using a variety of characterization techniques including Fourier Transform Infrared Spectroscopy (FTIR), scanning electron microscopy (SEM) as well as alamar blue, acridine orange, and alizarin red assays. Nanostructured ZOL-GO with an optimum performance is synthesized using $\mathrm{ZOL}$ and $\mathrm{GO}$ suspensions with the concentration of $50 \mu \mathrm{M}$ and $2.91 \mathrm{ng} / \mathrm{ml}$, respectively. ZOL-GO nanostructures can facilitate the mineralization of BM-MSC cells, demonstrated by the formation of clusters around the cells. The results obtained confirm the performance of ZOL-GO nanostructures as promising drug complexes for the treatment of osteoporosis and metastasis.
\end{abstract}

Secondary bone cancer (metastasis) occurs when cancer spreads to the bones from different organs including lung, kidney, thyroid ${ }^{1-3}$, and particularly from the prostate and breast, as observed in $70 \%$ of cases $^{2}$. Bisphosphonates have commonly been used for decades as a treatment for metastasis ${ }^{4,5}$. Zoledronic acid (ZOL) is a more recently developed bisphosphonate which is found to be more potent in the treatment of metastasis ${ }^{6-11}$. Despite this, the utilization of small ZOL molecules in this application is difficult, since the free drug can easily be filtrated before arriving at the tumor site ${ }^{12,13}$. As a result, higher doses of the drug must be administered which increases the chance for the occurrence of side effects, including acute systemic inflammatory reactions, osteonecrosis of the jaw, renal failure, nephrotic syndrome, electrolyte imbalance and ocular inflammation ${ }^{14-16}$. To increase the efficiency of the drug and reducing the chance of side effects, ZOL can be loaded on different drug carriers such as poly(lactide-co-glycolide $)^{17}$, folate targeted liposomes ${ }^{18}, \beta$-tricalcium phosphate ${ }^{19}$, hydroxyapatite $^{20}$ and gelatin ${ }^{21}$

Carbon allotropes show potential as alternatives to conventional drug carriers due to their high surface area and biocompatibility as well as the capability of being chemically modified ${ }^{22}$. In particular, graphene oxide (GO), carbon nanotubes (CNT), nanodiamond and carbon black are known to be capable of delivering drugs into cancer cells, improving the efficiency of the drug ${ }^{23}$. Among these carbons, GO has obvious advantages such as low cost, the presence of two external chemically active surfaces, easy fabrication and modification, and the absence of toxic metal particles during its production ${ }^{24}$. Studies also indicated that the loading capacity of GO is higher than $\mathrm{CNT}$ and carbon black ${ }^{25,26}$. Moreover, the degree of cytotoxicity of CNT and carbon black are found to be higher than $\mathrm{GO}^{27}$. Therefore, in this study, GO was chosen as the preferred carrier for ZOL.

$\mathrm{GO}$ is the oxidized form of graphene, functionalized with groups such as hydroxyls, epoxides, diols, ketones, and carboxyls ${ }^{28}$. GO has been used as a drug carrier for anti-cancer drugs such as doxorubicin ${ }^{29}$, $\operatorname{camptothecin}^{30}$, paclitaxe $^{31}$, pirfenidone $e^{32}$ and adriamycin ${ }^{30,33}$. Since both GO and ZOL contain aromatic rings in their chemical structure, ZOL could conjugate with GO by non-covalent $\pi-\pi$ interactions. Additionally, hydrogen bonding and hydrophobic interactions can also occur based on the ZOL and GO structures. Conjugation of ZOL on GO

${ }^{1}$ Boğaziçi University, Institute of Biomedical Engineering, İstanbul, Turkey, 34368. ${ }^{2}$ Northeastern University, College of Engineering, Boston, Massachusetts USA 02115, Boğaziçi University, Institute of Biomedical Engineering, İstanbul, Turkey, 34368. ${ }^{3}$ University of Manchester, Department of Physics and Astronomy, Manchester, M13 9PL, United Kingdom. ${ }^{4}$ Energy and Environmental Materials Research Centre (E2MC), School of Metallurgy, Northeastern University, Shenyang, China, 110819. ${ }^{\circledR}$-mail: duygu.ege@boun.edu.tr 


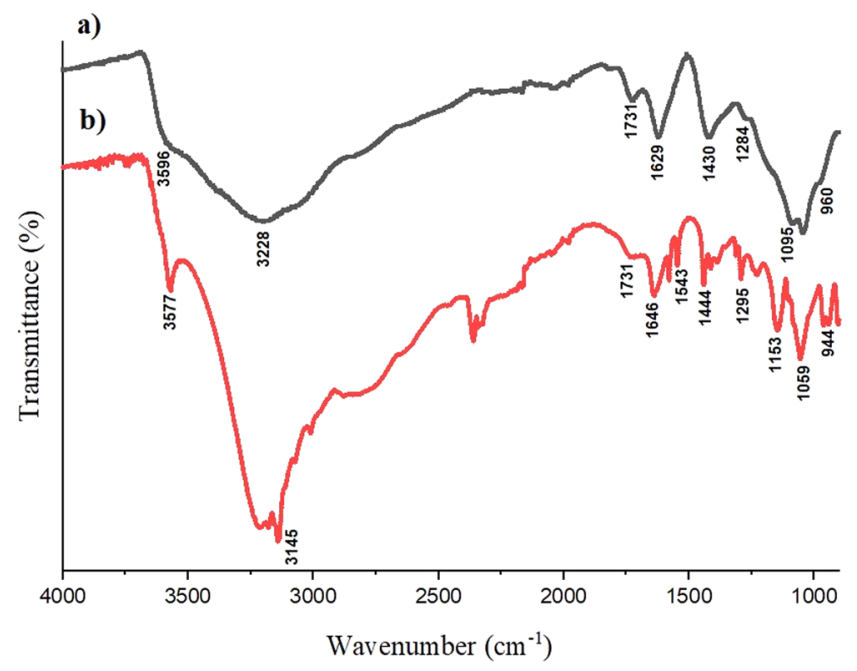

Figure 1. FTIR spectra of (a) GO, and (b) $200 \mu \mathrm{M}-11.7 \mathrm{ng} / \mathrm{ml} \mathrm{ZOL}-\mathrm{GO}$.

may increase the size of the complex reducing the fast renal filtration, and consequently, increasing the circulation time throughout the body ${ }^{12}$. Furthermore, the slow release of ZOL from GO may prevent harmful side effects which mostly result from the presence of high doses of the drug in the body ${ }^{34}$.

In this study, ZOL and GO were conjugated to increase the effect of ZOL on MCF-7 breast cancer cells and to elevate the mineralization of BM-MSCs. To this end, conjugated ZOL-GO complexes were prepared with different concentrations, and characterized by Alamar blue viability assay, Acridine orange staining, SEM morphological analysis and alizarin red staining. The results suggested that the conjugation of ZOL and GO did not affect the viability of MCF-7 breast cancer cells and BM-MSCs compared to pure ZOL. Despite this, the prepared complex significantly increased the degree of mineralization of BM-MSCs.

\section{Results}

Photonic characterization of the ZOL-GO complex. The FTIR spectra of GO and $200 \mu \mathrm{M}-11.7 \mathrm{ng} / \mathrm{ml}$ of ZOL-GO complex produced in this study are shown in Fig. 1.

In the FTIR spectrum of GO, the band at $3596,3228,1629$ and $1284 \mathrm{~cm}^{-1}$ characterize the stretching vibration mode of $\mathrm{O}-\mathrm{H}^{35,36}$. The band at $1731 \mathrm{~cm}^{-1}$ could be related to the $\mathrm{C}=\mathrm{O}$ stretching vibration from the carboxyl group ${ }^{35-38}$. The $\mathrm{O}-\mathrm{H}$ deformation vibration band was found at $1430 \mathrm{~cm}^{-138,39}$. The band at $1095 \mathrm{~cm}^{-1}$ possibly arose due to C-O functional group ${ }^{36}$. Moreover, the band at $960 \mathrm{~cm}^{-1} \mathrm{can}$ be ascribed to the epoxy groups in the GO structure ${ }^{37,38}$.

In the ZOL-GO spectrum, likewise to the case of GO, the bands at 3577 and $3145 \mathrm{~cm}^{-1}$ were related to the stretching vibration mode of $\mathrm{O}-\mathrm{H}$ groups ${ }^{35,36,40}$. Additionally, bands at 1543 and $1646 \mathrm{~cm}^{-1}$ are attributed to the vibration of $\mathrm{CH}=\mathrm{CH}$ groups in the imidazole rings; and the band at $944 \mathrm{~cm}^{-1}$ to the stretching vibration of $\mathrm{C}-\mathrm{C}$ bonds $\mathrm{s}^{40,41}$. The band at $1444 \mathrm{~cm}^{-1}$ can be attributed to stretching vibrations of $\mathrm{C}-\mathrm{H}$ bonds in the imidazole ring ${ }^{40-42}$. The bands found at 1153 and $1295 \mathrm{~cm}^{-1}$ possibly arise due to $\mathrm{P}-\mathrm{O}$ and $\mathrm{P}=\mathrm{O}$ stretching vibrations, respectively ${ }^{41}$.

In the spectrum of ZOL-GO, in addition to the bands found for ZOL, there were two bands related to GO. The band at $1731 \mathrm{~cm}^{-1}$ was possibly due to the $\mathrm{C}=\mathrm{O}$ stretching vibration from carboxyl groups of $\mathrm{GO}^{35-38}$. The band found at $1059 \mathrm{~cm}^{-1}$ possibly emerges due to the $\mathrm{C}-\mathrm{OH}$ functional group of $\mathrm{GO}$. The presence of these bands were proving conjugation of ZOLand GO.

The cell viability and morphology of MCF-7 breast cancer cells. Figure 2 shows the viability of MCF-7 cells after GO, ZOL and GO-ZOL treatments.

According to Fig. 2, MCF-7 cells had a significant viability decrease after the treatment with all ZOL and ZOL-GO complexes on day 3. Incorporation of pure GO also significantly effected the percentage viability of MCF-7 cells. The percentage viability of MCF-7 cells decreased to $76 \%$ after addition of $11.7 \mathrm{ng} / \mathrm{ml} \mathrm{GO}$ on day 7. After the treatment with $50 \mu \mathrm{M}$ and $200 \mu \mathrm{M}$ ZOL the percentage viability of MCF-7 cells dropped by $35 \%$. Conjugation of GO and ZOL did not alter the \%-viability of MCF-7 cells compared to ZOL.

Figure 3 clearly depicts the viability of MCF-7 cells after the different treatments.

According to Fig. 3, the viability of MCF-7 cells was $83 \%$ and $87 \%$ for TCP and $2.91 \mathrm{ng} / \mathrm{ml}$ of GO sample, respectively. With the addition of ZOL, a viability of $34 \%$ was observed. Moreover, the cell viability was significantly lower after the ZOL-GO treatment which was only 9\%. For the alamar blue assay, this drop was not as significant; however, the AO assay showed a more defined drop after the ZOL-GO treatment in comparison to the ZOL treatment. Table 1 shows percentage of live cells for different study groups.

Figure 4 shows SEM images of MCF-7 cells after treatment using ZOL and GO for 3 days.

The MCF-7 cells had similar morphology and cell population features after the GO treatment and on TCP. The ZOL treatment led to a decrease in the number of cells. 

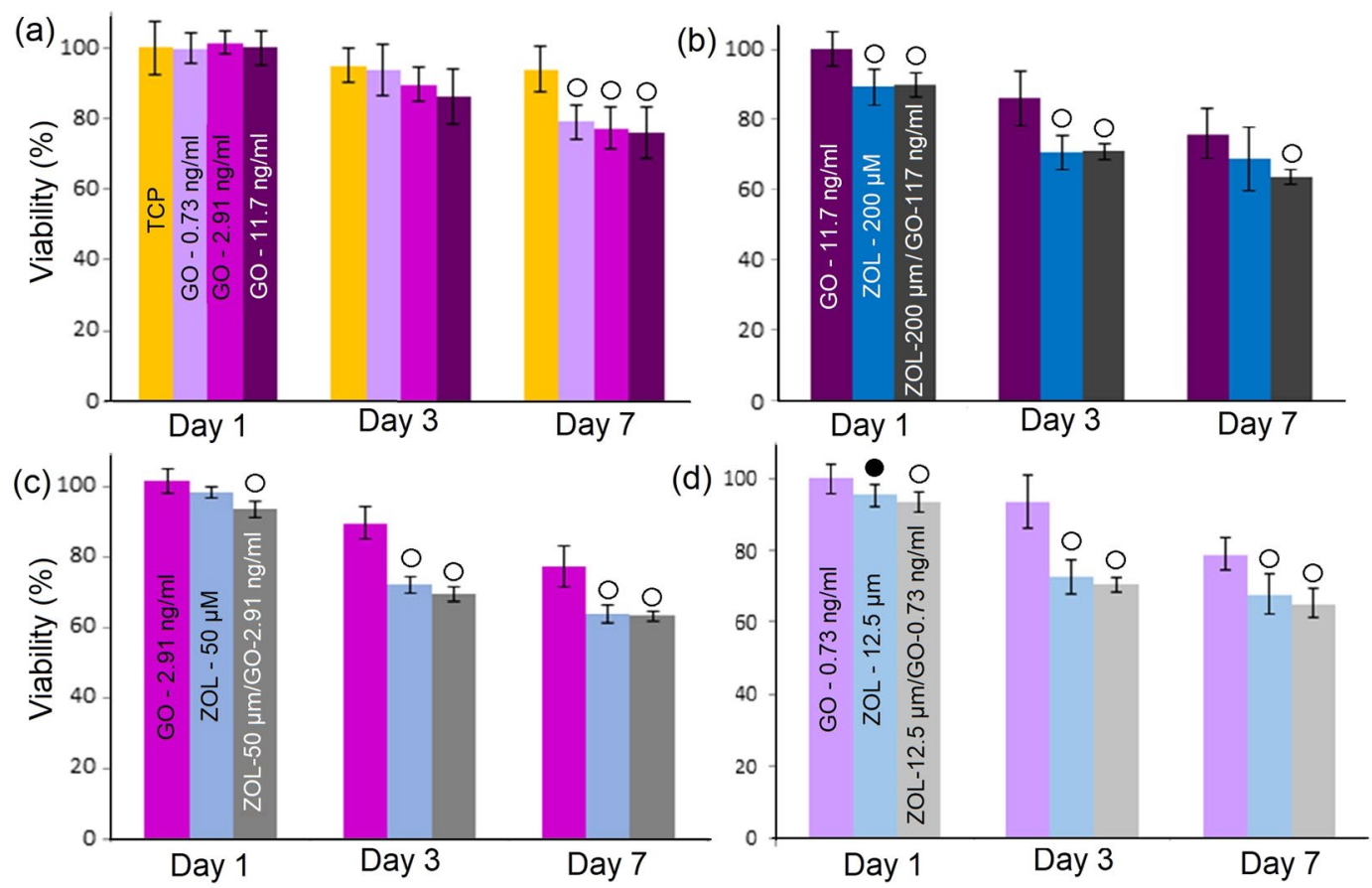

Figure 2. Percentage viability of MCF-7 cells after treatment with (a) different GO concentrations, and (bd) selected concentrations of GO, ZOL and ZOL-GO. Metabolic activity was normalized to day 1 of TCP. The significant differences between TCP and other study groups is indicated by ${ }^{\bullet}(\mathrm{P}<0.01 \mathrm{vs}$. control $)$ and ${ }^{\circ}$ $(\mathrm{P}<0.05)$.
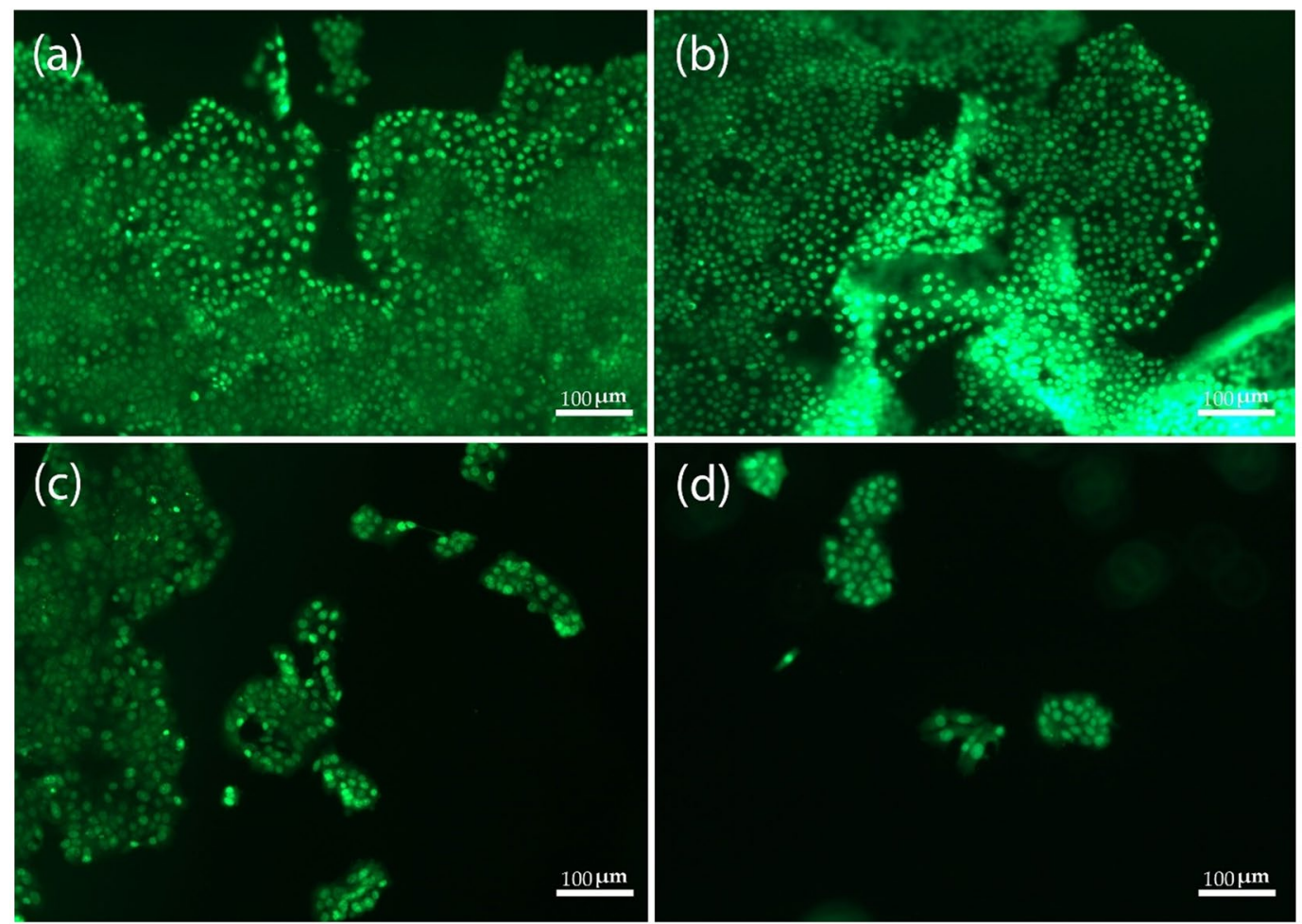

Figure 3. MCF-7 cells staining by AO. (a) TCP, and the samples treated with (b) $2.91 \mathrm{ng} / \mathrm{ml}$ of GO, (c) $50 \mu \mathrm{M}$ $\mathrm{ZOL}$ and (d) $50 \mu \mathrm{M} \mathrm{ZOL}-2.91 \mathrm{ng} / \mathrm{ml} \mathrm{GO}$, after 3 days. 


\begin{tabular}{|l|l|l|}
\hline $\begin{array}{l}\text { GO-ZOL } \\
\text { Samples }\end{array}$ & $\begin{array}{l}\text { GO concentration }(\mathbf{n g} / \\
\mathbf{m l})\end{array}$ & $\begin{array}{l}\text { ZOL concentration } \\
(\boldsymbol{\mu M})\end{array}$ \\
\hline 1 & 11.7 & 200 \\
\hline 2 & 2.91 & 50 \\
\hline 3 & 0.73 & 12.5 \\
\hline
\end{tabular}

Table 1. Composition of different ZOL-GO samples prepared.
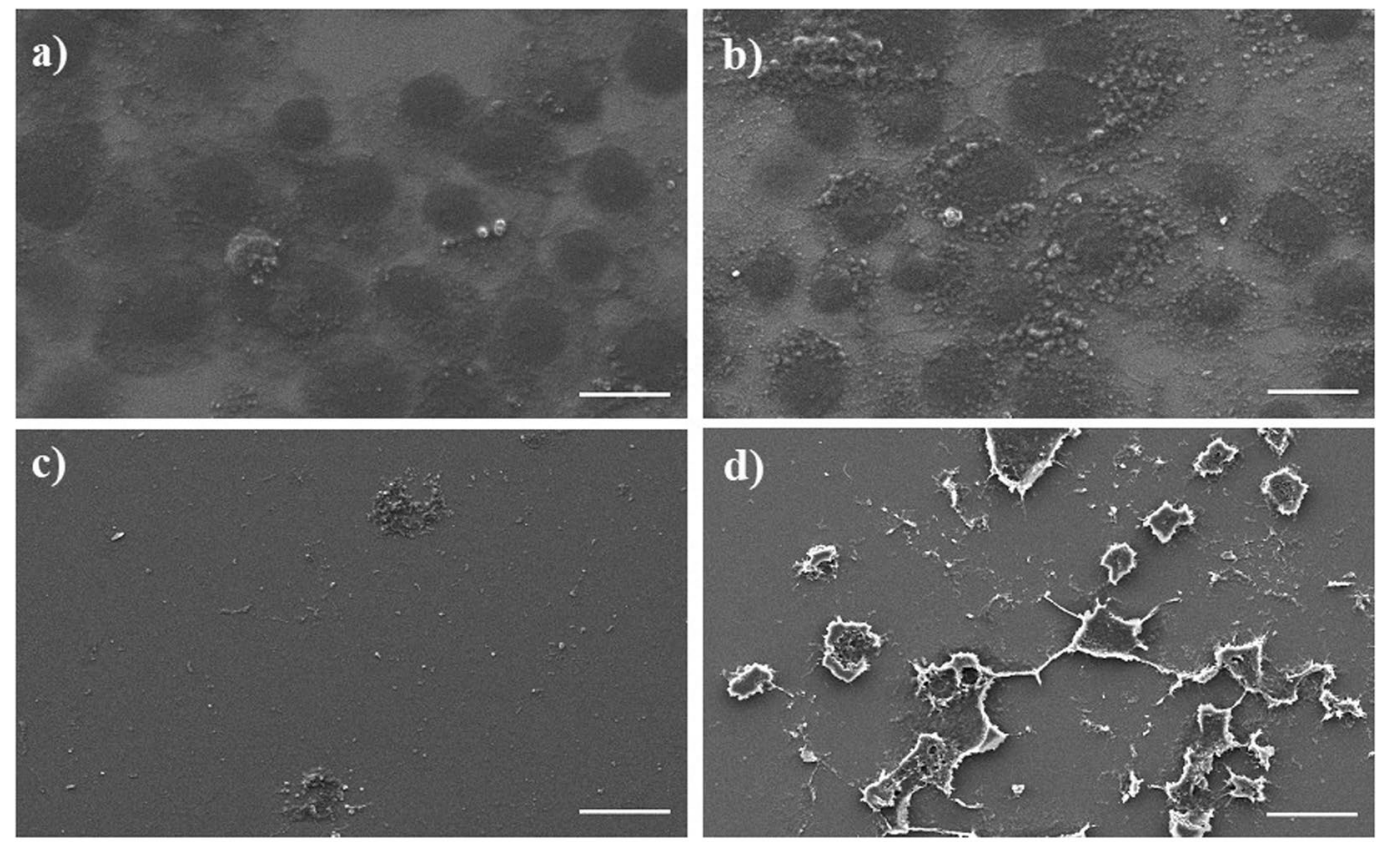

Figure 4. SEM images of MCF-7 cells after treatment using (a) TCP (b) $0.73 \mathrm{ng} / \mathrm{ml} \mathrm{GO}$ (c) $12.5 \mu \mathrm{M} \mathrm{ZOL}$ (d) $12.5 \mu \mathrm{M}-0.73 \mathrm{ng} / \mathrm{ml}$ ZOL-GO (scale bar: $20 \mu \mathrm{m}$ )

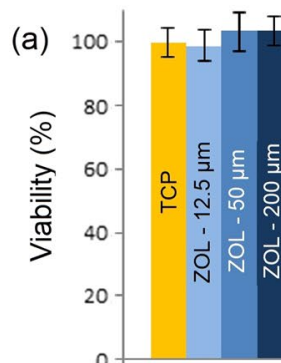

Day 1

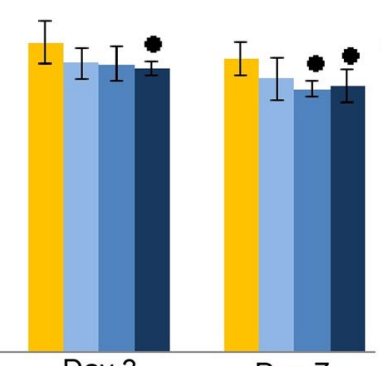

Day 3
Day 7

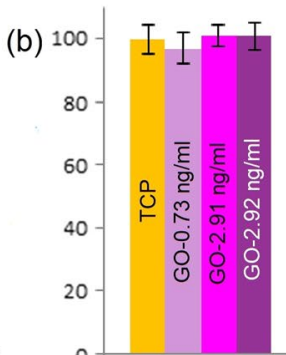

Day 1

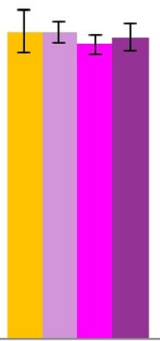

Day 3

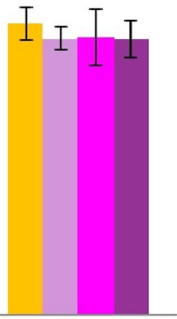

Day 7

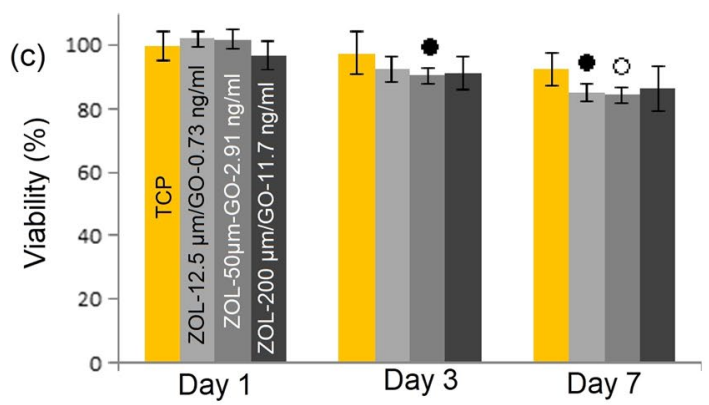

Figure 5. Percentage viability of MSC cells after treatment with different concentrations of (a) ZOL (b) GO and (c) ZOL-GO complexes (Metabolic activity was normalized to day 1 of TCP.) The significant differences between TCP and other study groups is indicated by $\bullet(\mathrm{P}<0.01$ vs. control $)$ and ${ }^{\circ}(\mathrm{P}<0.05)$. 

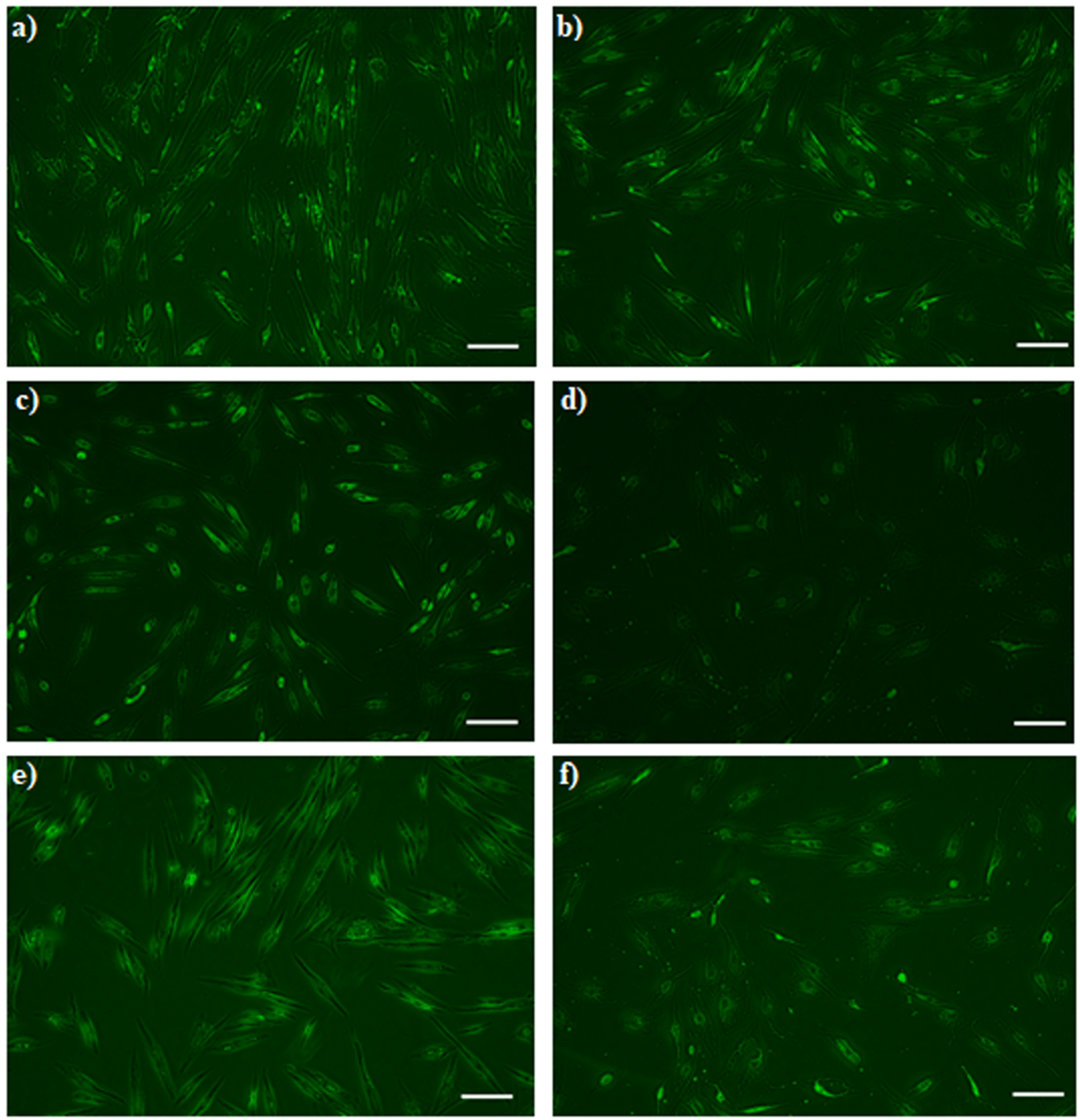

Figure 6. BM-MSCs staining by AO (a) $0.73 \mathrm{ng} / \mathrm{ml} \mathrm{GO}$ (b) $11.7 \mathrm{ng} / \mathrm{ml} \mathrm{GO}$ (c) $12.5 \mu \mathrm{M} \mathrm{ZOL}$ (d) $200 \mu \mathrm{M} \mathrm{ZOL}$ (e) $12.5 \mu \mathrm{M}$ ZOL-GO (f) $200 \mu \mathrm{M}$ ZOL-GO after 3 days (scale bar: $200 \mu \mathrm{m}$ ).

The cell viability of BM-MSCs. Figure 5 shows the viability of BM-MSCs after interaction with GO, ZOL and ZOL-GO complexes.

For BM-MSCs, pure GO did not significantly affect the viability of BM-MSCs with any of the concentrations used. ZOL did not cause a significant drop in the percentage cell viability on day 1 . On day 3 , there was only a considerable decrease for the concentration of $200 \mu \mathrm{M}$. On day 7 , considerable decreases were found for both 50 and $200 \mu \mathrm{M}$ ZOL. However, even on these days, the drop was only $8 \%$ larger than TCP. On the other hand, for ZOL-GO samples, on day 7, the most significant reduction of cells was observed for the $50 \mu \mathrm{M}-2.91 \mathrm{ng} / \mathrm{ml}$ ZOL-GO sample. This decrease was nevertheless still only $14 \%$ larger than TCP. The percentage of cell viability was over $83 \%$ for all study groups.

Figure 6 shows the viability of BM-MSCs after different treatments. Compared to TCP, with the addition of $0.73 \mathrm{ng} / \mathrm{ml} \mathrm{GO}$, the amount of BM-MSCs has increased, whilst the addition of $11.7 \mathrm{ng} / \mathrm{ml} \mathrm{GO}$, caused a slight decrease in the number of cells. With the addition of $12.5 \mu \mathrm{M} \mathrm{ZOL}$, no significant decrease of the cell content was observed. However, an increase of the ZOL concentration to $200 \mu \mathrm{M}$ significantly decreased the cell concentration, which was equivalent to the results obtained by the alamar blue assay (Fig. 5). For the cells treated with $12.5 \mu \mathrm{M}-0.73 \mathrm{ng} / \mathrm{ml} \mathrm{ZOL-GO}$, there was no decrease in the cell concentration compared to TCP. This was also paralleled by the results obtained by the alamar blue assay.

Additionally, in this case, the cells appeared to become more elongated, in comparison with the case observed in pure $0.73 \mathrm{ng} / \mathrm{ml} \mathrm{GO}$ or $12.5 \mu \mathrm{M}$ ZOL. For the cells treated with $200 \mu \mathrm{M}-11.7 \mathrm{ng} / \mathrm{ml} \mathrm{ZOL-GO}$, their MSC concentration was decreased. Despite this decrease, the cell concentration was much higher in comparison to the case of $200 \mu \mathrm{M}$ ZOL. Also, compared to $11.7 \mathrm{ng} / \mathrm{ml} \mathrm{GO}$, the cells concentration was not significantly decreased, confirming that GO had a positive impact on the viability of BM-MSCs when complexed with ZOL. 

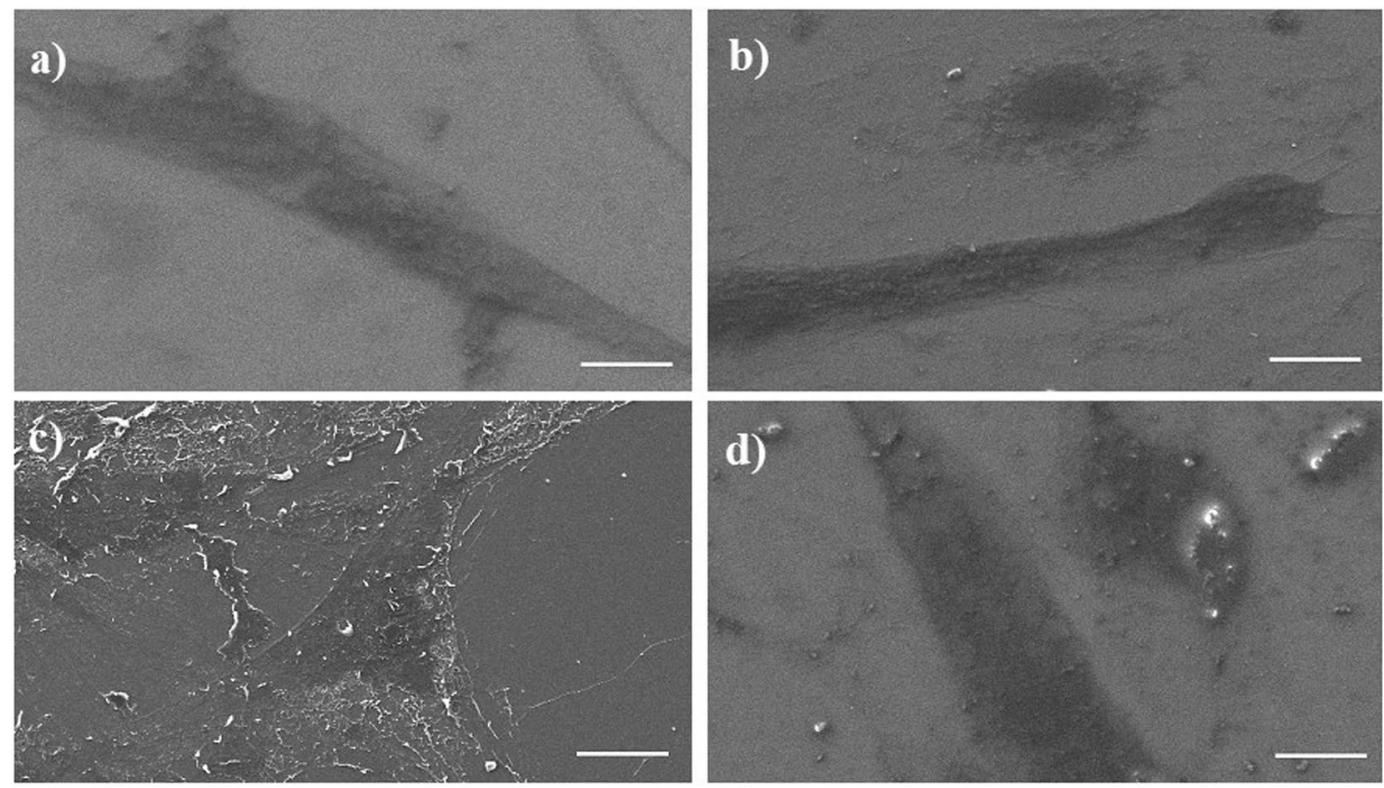

Figure 7. SEM images of BM-MSCs after treatment using (a) TCP, (b) $0.73 \mathrm{ng} / \mathrm{ml} \mathrm{GO,} \mathrm{(c)} 12.5 \mu \mathrm{M} \mathrm{ZOL} \mathrm{(d)}$ 12.5 $\mu \mathrm{M}$ ZOL $-0.73 \mathrm{ng} / \mathrm{ml} \mathrm{GO}$ (scale bar: $20 \mu \mathrm{m}$ ).

The cell morphology and mineralization of BM-MSCs. Figure 7 shows images of an SEM study of BM-MSCs after treatment using ZOL, GO and ZOL-GO for 3 days.

According to the images, BM-MSCs had a similar morphology after treatment with GO, ZOL-GO and TCP. Figure 8 shows the alizarin red results obtained on day 14 .

In general, on day 14, there was not much mineralization on the TCP and the GO treated samples. On the other hand, $12.5 \mu \mathrm{M}$ ZOL led to a significant amount of mineralization. The degree of mineralization disappeared with the increase of ZOL concentration to $200 \mu \mathrm{M}$. ZOL-GO with the lowest concentration also caused mineralization; however, samples treated with $200 \mu \mathrm{M}-11.7 \mathrm{ng} / \mathrm{ml}$ ZOL-GO showed no sign of mineralization. Figure 9 shows the alizarin red results on day 21.

On day $21, \mathrm{GO}$ treated samples with a concentration of 0.73 and $2.91 \mathrm{mg} / \mathrm{ml}$ exhibited mineralization; however, no mineralization was observed for $11.7 \mathrm{ng} / \mathrm{ml} \mathrm{GO}$. For ZOL samples, there was a significant degree of mineralization for $50 \mu \mathrm{M} \mathrm{ZOL}$, but no mineralization was observed for lower or higher concentrations. For ZOL-GO, there was a much more significant degree of mineralization than for pure $\mathrm{ZOL}$ for concentrations of $12.5 \mu \mathrm{M}$ and $50 \mu \mathrm{M}$ ZOL-GO. However, $200 \mu \mathrm{M}$ ZOL-GO treated sample showed a minimal degree of mineralization. According to the alizarin red results, $50 \mu \mathrm{M}$ ZOL significantly increased the mineralization of the cells.

\section{Discussion}

In this study ZOL-GO complexes were produced for potential drug delivery purposes. FTIR results indicated that the drug complexes were produced successfully. These observations were supporting our results from a preliminary study where we have proven conjugation of ZOL and GO by using UV-vis spectroscopy ${ }^{43}$.

Alamar blue result was in accordance to the results obtained by other groups which indicated that ZOL inhibits MCF-7 cell proliferation and invasion at a dose level of $50 \mu \mathrm{M}^{44}$. In the literature, the inhibition of breast cancer cells by ZOL was related to inhibition of farnesyl pyrophosphate (FPP) synthase in the mevalonate biosynthetic pathway ${ }^{13,45-47}$. Firstly, the inhibition of FPP synthase prevent prenylation of GTP-binding proteins such as Rho, Rac Ras and Rab due to depletion of farnesylpyrophosphate (FPP) and geranylgeranylphyrophosphate $(\text { GGPP })^{45,48-50}$. The prenylation of GTP-binding proteins are essential for cell survival and their impairment leads to cell apoptosis ${ }^{51}$. Secondly, FPP synthase inhibition leads to accumulation of isopentenyl pyrophosphate (IPP) and apoptotic ATP analogue (Apppl ${ }^{52}$. Apppl inhibit adenine nucleotide translocase in the mitochondria and IPP activates $\mathrm{V} \gamma 9 \mathrm{~V} \delta 2-\mathrm{T}$ cells which eliminate cancer cells ${ }^{45}$. The synergistic effect of ZOL and GO on the mevalonate pathway remains unknown and requires further research.

$\%$ cell viability observed via acridine orange assay shows that ZOL-GO provides a synergistic effect, reducing the \% viability of MCF-7 significantly more than if solely ZOL was used. This is possibly due to improvement of the drug efficiency in the presence of GO carrier. GO leads to the effective internalization of the drug to the cells by endocytosis and/or cell penetration through lipid bilayer ${ }^{53}$. Utilization of the ZOL-GO complex led to a morphological change in MCF-7 cells, which requires further investigations.

Alamar blue study on BM-MSCs showed that ZOL-GO complexes did not have a significantly adverse effect on BM-MSC. These results align with a number of other studies which also suggests that ZOL does not have a negative effect on BM-MSC viability ${ }^{5-57}$. Overall, ZOL and ZOL-GO complexes did not drastically decrease the viability of BM-MSCs, but more significantly that of MCF-7 cells, which is advantageous for bone metastasis treatment. 


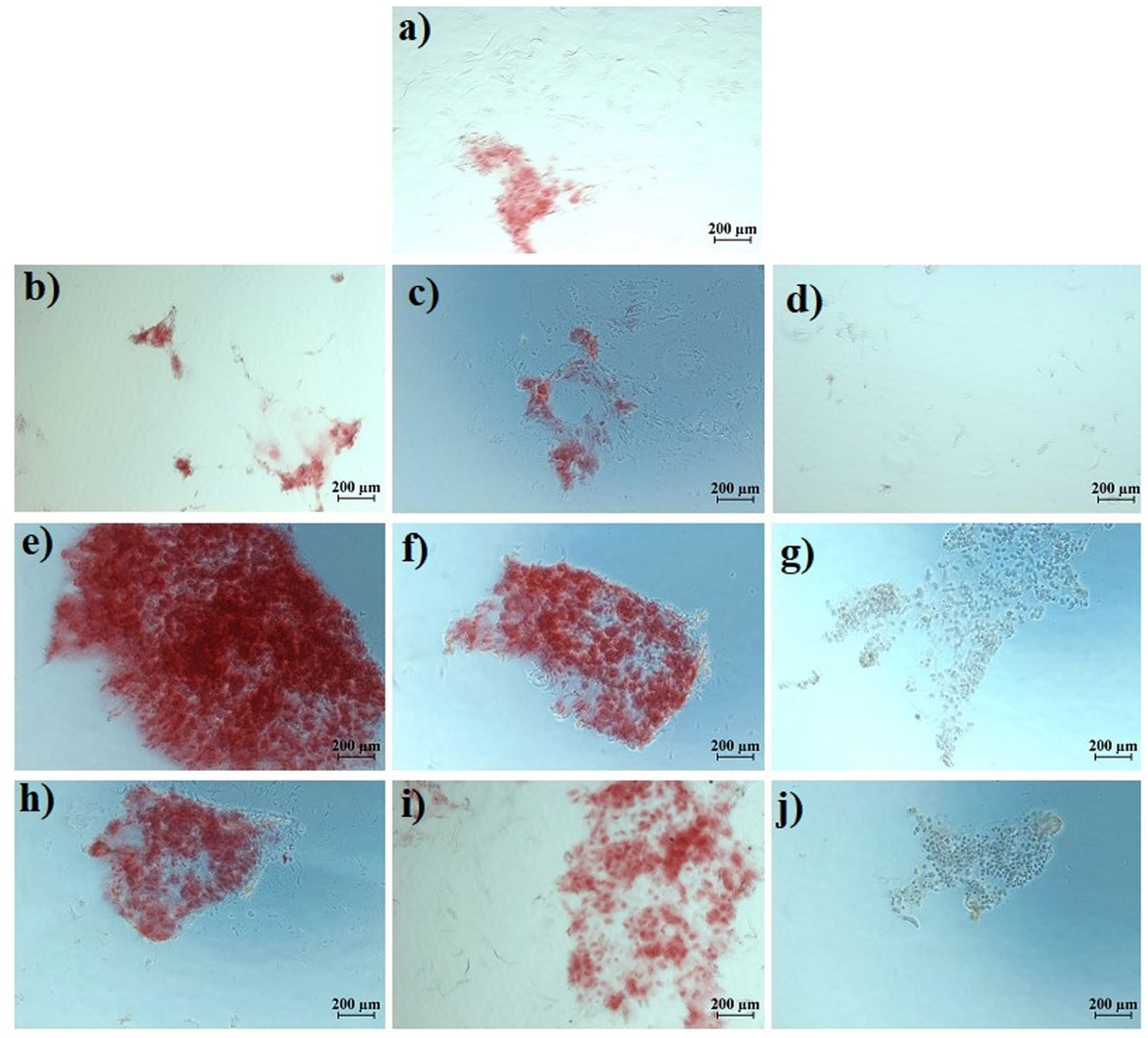

Figure 8. Alizarin red results of (a) TCP, (b) $0.73 \mathrm{ng} / \mathrm{ml} \mathrm{GO,} \mathrm{(c)} 2.91 \mathrm{ng} / \mathrm{ml} \mathrm{GO}$, (d) $11.7 \mathrm{ng} / \mathrm{ml} \mathrm{GO}$, (e) $12.5 \mu \mathrm{M}$ $\mathrm{ZOL}$, (f) $50 \mu \mathrm{M} \mathrm{ZOL}$, (g) $200 \mu \mathrm{M}$ ZOL, (h) $12.5 \mu \mathrm{M} Z \mathrm{ZOL}-0.73 \mathrm{ng} / \mathrm{ml} \mathrm{GO}$ (i), $50 \mu \mathrm{M}$ ZOL $-2.91 \mathrm{ng} / \mathrm{ml} \mathrm{GO}$, and (j) $200 \mu \mathrm{M}$ ZOL $-11.7 \mathrm{ng} / \mathrm{ml} \mathrm{GO}$, on the day 14 .

Moreover, acridine orange assay results indicated that ZOL-GO complex led to elongation of BM-MSCs. In the literature, the elongation of MSCs has been related to the differentiation of MSCs to osteoblasts ${ }^{58-60}$. In our study, the combination of GO and ZOL could possibly trigger the differentiation of cells to osteoblasts. Literature also suggests that both GO and ZOL are effective at differentiating MSCs to osteoblasts at certain concentrations ${ }^{61-63}$. At high concentrations, ZOL was found toxic to cells which led to decrease of $\%$ viability of BM-MSCs ${ }^{64,65}$.

Additionally, SEM results revealed that the samples treated with ZOL-GO shows the presence of clusters which might be due to the indicated mineralization of BM-MSCs. The morphology of ZOL treated samples exhibits a change, compared to the other samples, which could be due to mineralization of the cells under the influence of the ZOL treatment, which is in agreement with reports in the literature ${ }^{57,66}$. Ebert et al. ${ }^{57}$, Carbonare et al. ${ }^{62}$ and $\mathrm{Hu}$ et al. ${ }^{67}$ also indicated that at the $\mu \mathrm{M}$ level, bisphosphonates trigger the osteogenic differentiation of MSCs, leading to their mineralization. Additionally, GO also leads to mineralization of MSCs, therefore in this study we have observed a synergistic effect of ZOL-GO complexes on mineralization of MSCs ${ }^{61-63}$.

According to the studies of Igarashi et al. ${ }^{68}$ and Pan et al. ${ }^{69}$, the addition of $25 \mu \mathrm{M}$ ZOL increased the mineralization of cells. However, lower concentrations did not lead to a considerable degree of mineralization. Accordingly, Basso et al. ${ }^{70}$ also found inhibition of mineralization with application of only $5 \mu \mathrm{M}$ of ZOL on osteoblast cells. Vaisman et al. ${ }^{71}$ and Patntirapong et al. ${ }^{11}$ indicated that higher doses of ZOL than $100 \mu \mathrm{M}$ inhibited the mineralization of bone ${ }^{66}$. This is also in agreement with the results of the current study. Gao et al ${ }^{72}$ indicated that ZOL induces osteogenic differentiation and mineralization via inhibition of mammalian target of the rapamycin complex 1 (mTORC1) activity. This leads to an upregulation of the bone morphogenetic protein-2 (BMP-2) and osteocalcin $(\mathrm{OCN})$ gene expressions ${ }^{69,72}$. At higher doses, differentiation and mineralization were prevented via promotion of the mTORC1 activity ${ }^{72}$.

As indicated earlier, GO induces mineralization of cells $\mathrm{s}^{28,73-75}$. Therefore, in our case, the ZOL-GO complex exhibited a synergistic effect, improving the mineralization of cells to high degrees, greater than those obtained solely by GO or ZOL. The results obtained are interesting and provide an opportunity to enhance the efficiency of the ZOL drug by using carbon-based carriers. Future research should concern in vivo studies to evaluate the 

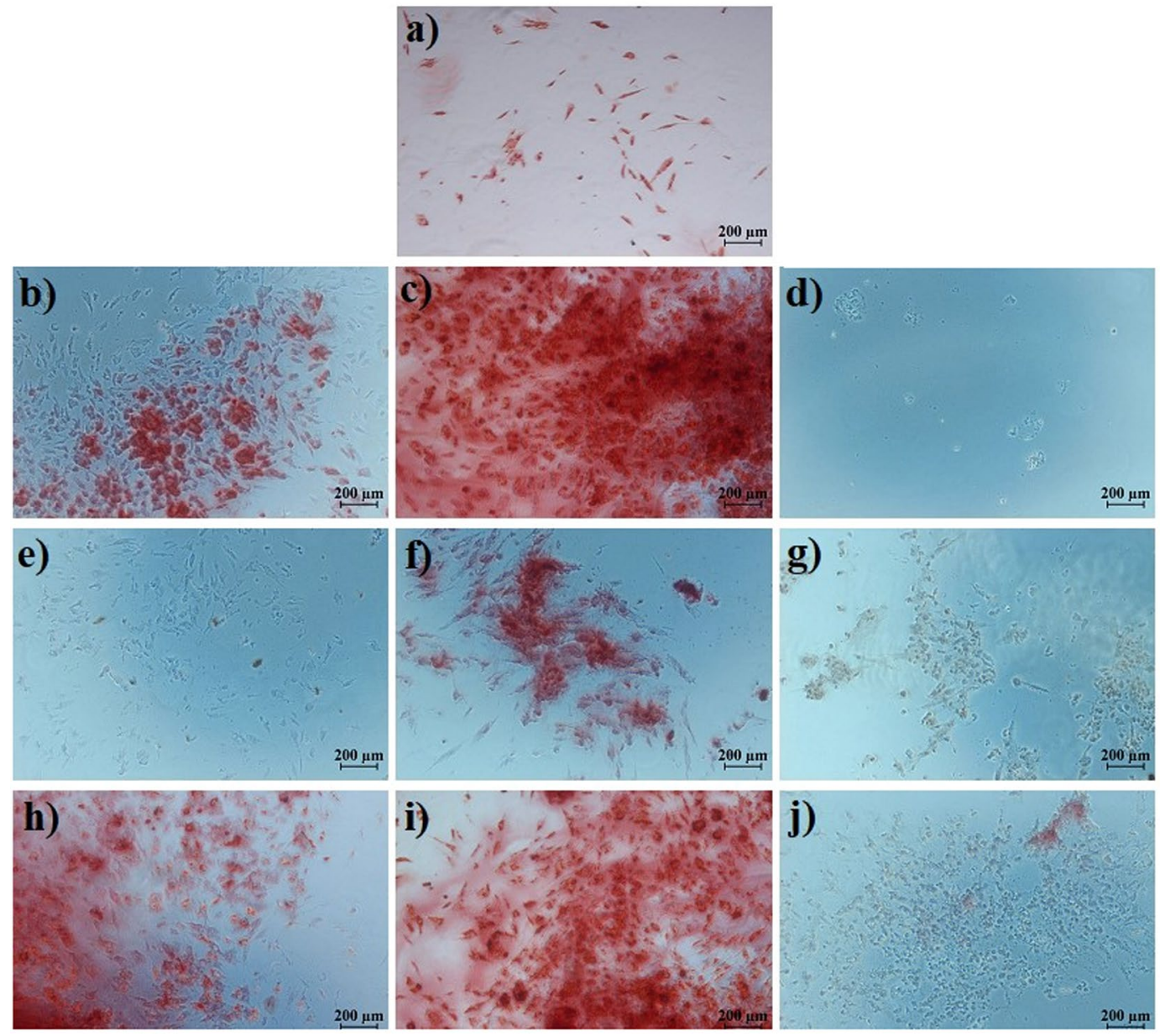

Figure 9. Alizarin red results (a) TCP, (b) $0.73 \mathrm{ng} / \mathrm{ml} \mathrm{GO,} \mathrm{(c)} 2.91 \mathrm{ng} / \mathrm{ml} \mathrm{GO}$, (d) $11.7 \mathrm{ng} / \mathrm{ml} \mathrm{GO}$, (e) $12.5 \mu \mathrm{M}$ ZOL, (f) $50 \mu \mathrm{M}$ ZOL, (g) $200 \mu \mathrm{M} Z \mathrm{ZOL}$, (h) $12.5 \mu \mathrm{M}$ ZOL- $0.73 \mathrm{ng} / \mathrm{ml} \mathrm{GO}$, (i) $50 \mu \mathrm{M} Z \mathrm{ZOL}-2.91 \mathrm{ng} / \mathrm{ml} \mathrm{GO}$, (j) $200 \mu \mathrm{M}$ ZOL $-11.7 \mathrm{ng} / \mathrm{ml} \mathrm{GO}$, on the day 21 .

performance of ZOL-GO complex structures in more details. Animal models may be used after conducting an appropriate harm-benefit analysis, considering animal rights and ethical issues beforehand. Moreover, anti-cancer effects should be studied correlating interactions with gene expressions, such as Bax and Bcl-2.

\section{Conclusion}

In this study, different concentrations of GO were loaded on ZOL, and the effects of ZOL, GO and ZOL-GO complexes on the characteristics of the BM-MSCs and MCF-7 cell lines were studied. ZOL did not significantly reduce the viability of BM-MSCs, and GO had no effect on the viability of BM-MSCs. On the other hand, both ZOL and ZOL-GO complexes significantly decreased the viability of MCF-7 cells. Staining of cells led to results that were equivalent to the alamar blue study. Alizarin red results showed that ZOL with a concentration of $50 \mu \mathrm{M}$ induces a high degree of mineralization. This was significantly increased with the addition of GO to $50 \mu \mathrm{M} Z \mathrm{ZOL}$. Overall, the results revealed that ZOL-GO complexes could decrease the viability of MCF-7 breast cancer cells, whilst they did not drastically affect the viability of BM-MSCs. Additionally, $50 \mu \mathrm{M}-2.91 \mathrm{ng} / \mathrm{ml}$ ZOL-GO caused a significant degree of BM-MSCs mineralization. Such ZOL-GO complexes show a promising performance for the drug treatment of osteoporosis and metastasis.

\section{Experimental}

Preparation of ZOL, GO and complexes. To prepare ZOL samples, $5 \mathrm{ml}$ of ultra-pure water was added to $10 \mathrm{mg}$ of zoledronic acid monohydrate (Sigma-Aldrich, $>98 \%$, HPLC) to obtain the stock solution with a concentration of $2 \mathrm{mg} / \mathrm{ml}$. Then, three different samples with concentrations of 12.5, 50 and $200 \mu \mathrm{M}$ were obtained by diluting the stock solution with DMEM (Dulbecco's Modified Eagle Medium), and magnetically stirring (Isolab-340) over night. To prepare various concentrations of GO, $4.5 \mathrm{ml}$ of ultra-pure water was added to $0.5 \mathrm{ml}$ of GO (Sigma- Aldrich, $2 \mathrm{mg} / \mathrm{ml}$, mean sheet diameter: $22 \mu \mathrm{m}$ ) to form the stock solution which was stirred by a vortex at room temperature for $30 \mathrm{~min}$. The stock solution was then diluted with DMEM and stirred for $30 \mathrm{~min}$ utes by a sonicator to obtain solutions with $\mathrm{GO}$ amounts of $11.7,2.91$ and $0.73 \mathrm{ng} / \mathrm{ml}$. 


\begin{tabular}{|l|l|}
\hline Sample groups & \% of live cells \\
\hline TCP & 83 \\
\hline GO & 87 \\
\hline ZOL & 34 \\
\hline ZOL-GO & 9 \\
\hline
\end{tabular}

Table 2. Percentage of live MCF-7 cells for different study groups.

Finally, ZOL-GO complexes with different compositions were prepared by mixing of the GO and ZOL suspensions, as shown in Table 2. To dilute GO and ZOL suspensions in order to achieve the required concentrations, the stock solutions were diluted with DMEM, stirred by the sonicator for $15 \mathrm{~min}$, and then magnetically stirred overnight.

Characterization methods. FTIR spectroscopy was performed by using Nicolet FTIR Instruments, Thermofischer to analyze the chemical structure of $\mathrm{ZOL}$ conjugation with $\mathrm{GO}$ at the wavenumber regime from 4000 to $400 \mathrm{~cm}^{-1}$ with a $2 \mathrm{~cm}^{-1}$ resolution ${ }^{76}$.

To study the performance of ZOL-GO drug complexes, cell culture studies were carried out using the human breast cancer cell line (MCF-7, ATCC HTB-22) and human bone marrow-derived MSCs (BM-MSCs, ATCC PCS-500-012).

For the alamar Blue assay, the cell line of MCF-7 cells were plated in a 96 well-plate (Sigma) with a density of $5 \times 10^{3} \mathrm{cell} / \mathrm{cm}^{2,77}$ and BM-MSC with a density of $2 \times 10^{3} \mathrm{cell} / \mathrm{cm}^{2}$ in complete growth medium with DMEM (Sigma), $10 \%$ Fetal Bovine Serum (FBS) (Sigma) and $1 \%$ penicillin/streptomycin (Sigma) at $37^{\circ} \mathrm{C}$ with $5 \% \mathrm{CO}_{2}{ }^{67}$. For BM-MSC, additionally, $4 \mathrm{mM} \mathrm{L-Glutamine} \mathrm{(Sigma)} \mathrm{was} \mathrm{added} \mathrm{into} \mathrm{the} \mathrm{growth} \mathrm{medium.} 24$ hours after seeding of the cells, they were treated with samples including ZOL, GO and ZOL-GO complexes in total growth medium. The drug treatment in this assay was applied on day 1,3, and 7. For the alamar blue assay, $10 \%$ of alamar blue solution (Sigma) was mixed with DMEM and $100 \mu \mathrm{l}$ of the prepared solution was added in each well on day 1,3 , and $7^{78}$. A microplate reader (BIO-RAD Mark, Microplate Reader) was used to study viability of the cells ${ }^{79}$. Statistical analyses were conducted by one-way analysis of variance (ANOVA) with post-hoc Tukey test.

Both BM-MSC and MCF-7 cells were seeded in a 48 well-plate at a density of $7.5 \times 10^{3}$ cells per well and were incubated with the complete medium overnight. Then, cells were treated with the samples for 3 days. The wells were washed with the media twice and Acridine orange (AO) was added to the wells to stain the live cells. Images were taken after a few seconds by inverted phase contrast microscopy. Open-source software ImageJ was used to calculate the percentage of live MCF-7 cells for AO staining.

A FEI-Philips XL30 Environmental Scanning Electron Microscope (SEM) with Field Emission Gun, equipped with an Energy Dispersive X-ray (EDX) analyzer, was used operating at $5 \mathrm{kV}$ in the secondary electron imaging mode for the study of morphological changes of BM-MSC and MCF-7 cells after the drug treatment on day 3. For the investigations, $2.5 \%$ glutaraldehyde was added on the cells for the fixation purpose in a dark room. For dehydration, the samples were immersed in $30 \%, 50 \%, 80 \%$, and $95 \%$ ethanol for 2 minutes each. Then, the ethanol was removed and a few droplets of hexamethyldisilazan (HMDS) were added. The samples were left to become dry overnight ${ }^{80}$.

For alizarin red staining, BM-MSC with a density of $10 \times 10^{3} \mathrm{cell} / \mathrm{cm}^{2}$ was seeded in a 24 well-plate and treated with the growth medium. After 24 hours, the cells were treated with osteogenic differentiation medium, comprising of the complete growth medium, $50 \mu \mathrm{g} / \mathrm{ml}$ of L-Ascorbic acid-2-phosphate, $5 \mathrm{mM}$ of $\beta$-Glycerophosphate and $10 \mathrm{nM}$ of Dexamethasone; all purchased from Sigma, to achieve final concentrations as shown in Table 1. The osteogenic differentiation medium was changed every 2 or 3 days. Alizarin red salt was used for the staining of free calcium ions and certain calcium compounds as an indicator of the mineralization. First, cells were fixed with $4 \%$ paraformaldehyde and 3xDPBS for 30 minutes at $4{ }^{\circ} \mathrm{C}$ and then washed with Dulbecco's phosphate-buffered saline (DPBS) twice ${ }^{81}$. Thereafter, $2 \%$ alizarin Red $S$ was added and the suspension was kept for 45 minutes in the dark at room temperature. The solution was removed and cells were washed with DPBS. Then, cells were observed by fluorescence microscopy (Axio Vert A.1-Zeiss) on days 14 and 21.

Received: 26 February 2020; Accepted: 21 April 2020;

Published online: 08 May 2020

\section{References}

1. Schmid-Alliana, A. et al. Understanding the progression of bone metastases to identify novel therapeutic targets. Int. J. Mol. Sci. 19, 148-168 (2018)

2. Macedo, F. et al. Bone metastases: An overview. Oncol. Rev. 11, 43-49 (2017).

3. Svensson, E., Christiansen, C. F., Ulrichsen, S. P., Rørth, M. R. \& Sørensen, H. T. Survival after bone metastasis by primary cancer type: A Danish population-based cohort study. BMJ Open 7, 1-7 (2017).

4. Fournier, P. G., Stresing, V., Ebetino, F. H. \& Clézardin, P. How do bisphosphonates inhibit bone metastasis in vivo? Neoplasia 12, 571-8 (2010)

5. Junankar, S. \& Rogers, M. J. In Bone Cancer 615-627 (Elsevier, 2015).

6. Nadar, R. A. et al. Bisphosphonate-Functionalized Imaging Agents, Anti-Tumor Agents and Nanocarriers for Treatment of Bone Cancer. Adv. Healthc. Mater. 6, 1601119-1601137 (2017).

7. Polascik, T. J. Bisphosphonates in oncology: Evidence for the prevention of skeletal events in patients with bone metastases. Drug Des. Devel. Ther. 3, 27-40 (2009). 
8. Torger, B. et al. Cast adhesive polyelectrolyte complex particle films of unmodified or maltose-modified poly (ethyleneimine) and cellulose sulphate: Fabrication, film stability and retarded release of zoledronate. Biointerphases 8, 1-11 (2013).

9. Jagdev, S. P., Coleman, R. E., Shipman, C. M., Rostami-H, A. \& Croucher, P. I. The bisphosphonate, zoledronic acid, induces apoptosis of breast cancer cells: Evidence for synergy with paclitaxel. Br. J. Cancer 84, 1126-1134 (2001).

10. Kellinsalmi, M. et al. In vitro Comparison of Clodronate, Pamidronate and Zoledronic Acid Effects on Rat Osteoclasts and Human Stem Cell-Derived Osteoblasts. J. Pharmacol. Toxicol. 97, 382-391 (2005).

11. Patntirapong, S., Singhatanadgit, W. \& Chanruangvanit, C. Zoledronic acid suppresses mineralization through direct cytotoxicity and osteoblast differentiation inhibition. J. Oral Pathol. Med. 41, 713-720 (2012).

12. Lin, J. H. Bisphosphonates: A review of their pharmacokinetic properties. Bone 18, 75-85 (1996).

13. Göbel, A. et al. Combined inhibition of the mevalonate pathway with statins and zoledronic acid potentiates their anti-tumor effects in human breast cancer cells. Cancer Lett. 375, 162-171 (2016).

14. Tanvetyanon, T. \& Stiff, P. J. Management of the adverse effects associated with intravenous bisphosphonates. An. Oncol. 17, 897-907 (2006).

15. Shane, E., Khosla, S. \& Burr, D. in Osteoporosis 1873-1883 (Academic Press, 2013).

16. Khajuria, D. K., Vasireddi, R., Trebbin, M., Karasik, D. \& Razdan, R. Novel therapeutic intervention for osteoporosis prepared with strontium hydroxyapatite and zoledronic acid: In vitro and pharmacodynamic evaluation. Mater. Sci. Eng. C 71, 698-708 (2017).

17. Gou, W. et al. Controlled delivery of zoledronate improved bone formation locally In Vivo. PLoS One 9, 1-9 (2014).

18. Shmeeda, H. et al. Delivery of zoledronic acid encapsulated in folate-targeted liposome results in potent in vitro cytotoxic activity on tumor cells. J. Control. Release 146, 76-83 (2010).

19. Kadow-Romacker, A., Greiner, S., Schmidmaier, G. \& Wildemann, B. Effect of $\beta$-tricalcium phosphate coated with zoledronic acid on human osteoblasts and human osteoclasts in vitro. J. Biomater. Appl. 27, 577-585 (2013).

20. Raina, D. B. et al. A Biphasic Calcium Sulphate/Hydroxyapatite Carrier Containing Bone Morphogenic Protein-2 and Zoledronic Acid Generates Bone. Sci. Rep. 6, 1-13 (2016).

21. Raina, D. B. et al. Gelatin- hydroxyapatite- calcium sulphate based biomaterial for long term sustained delivery of bone morphogenic protein-2 and zoledronic acid for increased bone formation: In-vitro and in-vivo carrier properties. J. Control. Release 272, 83-96 (2018).

22. Liu, Z., Robinson, J. T., Tabakman, S. M., Yang, K. \& Dai, H. Carbon materials for drug delivery \& cancer therapy. Mater. Today 14, 316-323 (2011).

23. Lim, D. J., Sim, M., Oh, L., Lim, K. \& Park, H. Carbon-based drug delivery carriers for cancer therapy. Arch. Pharm. Res. 37, 43-52 (2014).

24. Banks, C. E., Crossley, A., Salter, C., Wilkins, S. J. \& Compton, R. G. Carbon nanotubes contain metal impurities which are responsible for the 'electrocatalysis' seen at some nanotube-modified electrodes. Angew. Chemie - Int. Ed. 45, 2533-2537 (2006).

25. Zhang, R. \& Olin, H. Carbon nanomaterials as drug carriers: Real time drug release investigation. Mater. Sci. Eng. C 32, 1247-1252 (2012).

26. Sahoo, N. G. et al. Functionalized carbon nanomaterials as nanocarriers for loading and delivery of a poorly water-soluble anticancer drug: A comparative study. Chem. Commun. 47, 5235-5237 (2011).

27. Pan, Y., Sahoo, N. G. \& Li, L. The application of graphene oxide in drug delivery. Expert Opin. Drug Deliv. 9, 1365-1376 (2012).

28. Ege, D., Kamali, A. R. \& Boccaccini, A. R. Graphene Oxide/Polymer-Based Biomaterials. Adv. Eng. Mater. 1700627, 16-34 (2017).

29. Yang, X. et al. High-efficiency loading and controlled release of doxorubicin hydrochloride on graphene oxide. J. Phys. Chem. C 112, 17554-17558 (2008).

30. Wu, J. et al. Graphene oxide used as a carrier for adriamycin can reverse drug resistance in breast cancer cells. Nanotechnology 23, $1-9(2012)$.

31. Hussien, N. A., Işıklan, N. \& Türk, M. Pectin-conjugated magnetic graphene oxide nanohybrid as a novel drug carrier for paclitaxel delivery. Artif. Cells, Nanomedicine Biotechnol. 46, 264-273 (2018).

32. Yang, L. et al. Functionalized graphene oxide as a drug carrier for loading pirfenidone in treatment of subarachnoid hemorrhage. Colloids Surfaces B Biointerfaces 129, 21-29 (2015).

33. Gautam, S. Graphene Oxide: A Potential Drug Carrier for Cancer Therapy — Review. Res. Rev. A J. Pharm. Sci. 8, 20-31 (2018).

34. Tiwari, G. et al. Drug delivery systems_ An updated review. Int J Pharm Investig. 2, 2-11 (2012).

35. Zhang, X., Hu, W., Li, J., Tao, L. \& Wei, Y. A comparative study of cellular uptake and cytotoxicity of multi-walled carbon nanotubes, graphene oxide, and nanodiamond. Toxicol. Res. (Camb). 1, 62-68 (2012).

36. Manoratne, C. H., Rosa, S. R. D. \& Kottegoda, I. R. M. XRD-HTA, UV Visible, FTIR and SEM Interpretation of Reduced Graphene Oxide Synthesized from High Purity Vein Graphite. Mater. Sci. Res. India 14, 19-30 (2017).

37. Parades, J. I., Villar-Rodil, S., Martínez-Alonso, A. \& Tascón, J. M. D. Graphene oxide dispersions in organic solvents. Langmuir 24, 10560-10564 (2008).

38. He, D. et al. Mechanism of a green graphene oxide reduction with reusable potassium carbonate. RSC Adv. 5, 11966-11972 (2015).

39. Çiplak, Z., Yildiz, N. \& Cąlimli, A. Investigation of graphene/Ag nanocomposites synthesis parameters for two different synthesis methods. Fullerenes Nanotub. Carbon Nanostructures 23, 361-370 (2015).

40. Khajuria, D. K., Razdan, R. \& Mahapatra, D. R. Development, in vitro and in vivo characterization of zoledronic acid functionalized hydroxyapatite nanoparticle based formulation for treatment of osteoporosis in animal model. Eur. J. Pharm. Sci. 66, 173-183 (2015)

41. Prasanthi, M. M., Rao, B. A., Rao, B. V. N., Krishna, Y. P. \& Ramana, D. V. Formulation and Evaluation of Zoledronic Acid for Injection By Lyophilization Technique. Int. Res. J. Pharm. 8, 50-56 (2017).

42. Chen, S., Wan, P., Zhang, B., Yang, K. \& Li, Y. Facile fabrication of the zoledronate-incorporated coating on magnesium alloy for orthopaedic implants. J. Orthop. Transl. (2019).

43. Tavakoli, S. \& Ege, D. Graphene Oxide as a drug carrier for delivery of zoledronic acid in secondary bone cancer treatment. MRS Adv. 4, 1231-1235 (2019).

44. Ural, A. U., Avcu, F., Candir, M., Guden, M. \& Ozcan, M. A. In vitro synergistic cytoreductive effects of zoledronic acid and radiation on breast cancer cells. Breast Cancer Res. 8, R52-R59 (2006).

45. Zlatev, H. P., Auriola, S., Mönkkönen, J. \& Määttä, J. A. Uptake of free, calcium-bound and liposomal encapsulated nitrogen containing bisphosphonates by breast cancer cells. Eur. J. Pharm. Sci. 86, 58-66 (2016).

46. Park, Y. E. et al. Bone-Bound Bisphosphonates Inhibit Proliferation of Breast Cancer Cells. Calcif. Tissue Int. 105, 497-505 (2019).

47. Waller, D. D., Park, J. \& Tsantrizos, Y. S. Inhibition of farnesyl pyrophosphate (FPP) and/or geranylgeranyl pyrophosphate (GGPP) biosynthesis and its implication in the treatment of cancers. Crit. Rev. Biochem. Mol. Biol. 54, 41-60 (2019).

48. Elsayed, M. et al. Synergistic antiproliferative effects of zoledronic acid and fluvastatin on human pancreatic cancer cell lines: An in Vitro study. Biol. Pharm. Bull. 39, 1238-1246 (2016).

49. Agabiti, S. S., Yilan, L. \& Wiemer, A. J. Molecular mechanisms linking geranylgeranyl diphosphate synthase to cell survival and proliferation. Mol. Membr. Biol. 33, 1-11 (2016).

50. Waller, D. D., Park, J. \& Tsantrizos, Y. S. Inhibition of farnesyl pyrophosphate (FPP) and/or geranylgeranyl pyrophosphate (GGPP) biosynthesis and its implication in the treatment of cancers. Crit. Rev. Biochem. Mol. Biol. 54, 41-60 (2019).

51. Park, J., Matralis, A. N., Berghuis, A. M. \& Tsantrizos, Y. S. Human isoprenoid synthase enzymes as therapeutic targets. Front. Chem. 2, 1-21 (2014) 
52. Räikkönen, J., Mönkkönen, H., Auriola, S. \& Mönkkönen, J. Mevalonate pathway intermediates downregulate zoledronic acidinduced isopentenyl pyrophosphate and ATP analog formation in human breast cancer cells. Biochem. Pharmacol. 79, 777-783 (2010).

53. Mohajeri, M., Behnam, B. \& Sahebkar, A. Biomedical applications of carbon nanomaterials: Drug and gene delivery potentials. J. Cell. Physiol. 234, 298-319 (2018).

54. Schindeler, A. \& Little, D. G. Osteoclasts but not osteoblasts are affected by a calcified surface treated with zoledronic acid in vitro. Biochem. Biophys. Res. Commun. 338, 710-716 (2005).

55. Recker, R. R. et al. Effects of intravenous zoledronic acid once yearly on bone remodeling and bone structure. J. Bone Miner. Res. 23, 6-16 (2008).

56. Peter, B. et al. Calcium phosphate drug delivery system: Influence of local zoledronate release on bone implant osteointegration. Bone 36, 52-60 (2005).

57. Ebert, R. et al. Pulse treatment with zoledronic acid causes sustained commitment of bone marrow derived mesenchymal stem cells for osteogenic differentiation. Bone 44, 858-864 (2009).

58. Frandsen, C. J., Brammer, K. S. \& Jin, S. Variations to the nanotube surface for bone regeneration. Int. J. Biomater. 2013, 1-10 (2013).

59. Logan, N. \& Brett, P. The control of mesenchymal stromal cell osteogenic differentiation through modified surfaces. Stem Cells Int. 2013, $1-10$ (2013)

60. Allan, C. et al. Osteoblast response to disordered nanotopography. J. Tissue Eng. 9, 1-7 (2018).

61. Boccaccini, A. R., Ege, D., Kamali, A. R. \& Boccaccini, A. R. Graphene Oxide / Polymer-Based Biomaterials Graphene Oxide / Polymer-Based Biomaterials. Adv. Eng. Mater. 1700627, 16-34 (2017).

62. Carbonare, L. D. et al. Enhanced osteogenic differentiation in zoledronate-treated osteoporotic patients. Int. J. Mol. Sci. 18, 1-12 (2017).

63. Kolanthai, E. et al. Graphene Oxide - A Tool for the Preparation of Chemically Crosslinking Free Alginate-Chitosan-Collagen Scaffolds for Bone Tissue Engineering. ACS Appl. Mater. Interfaces 10, 12441-12452 (2018).

64. Ou, L. et al. Toxicity of graphene-family nanoparticles: A general review of the origins and mechanisms. Part. Fibre Toxicol. 13, $57-81$ (2016).

65. Basso, F. G. et al. Response of a co-culture model of epithelial cells and gingival fibroblasts to zoledronic acid. Braz. Oral Res. 30, e122 (2016).

66. Pozzi, S. et al. High-Dose Zoledronic Acid Impacts Bone Remodeling with Effects on Osteoblastic Lineage and Bone Mechanical Properties. Clin. Cancer Res. 15, 5829-5840 (2009).

67. Hu, L. et al. Pretreatment with Bisphosphonate Enhances Osteogenesis of Bone Marrow Mesenchymal Stem Cells. Stem Cells Dev. 26, 123-132 (2016)

68. Igarashi, K., Hirafuji, M., Adachi, H., Shinoda, H. \& Mitani, H. Effects of bisphosphonates on alkaline phosphatase activity, mineralization, and prostaglandin E2 synthesis in the clonal osteoblast-like cell line MC3T3-E1. Prostaglandins Leukot. Essent. Fat. Acids 56, 121-125 (1997).

69. Pan, B. et al. The nitrogen-containing bisphosphonate, zoledronic acid, increases mineralisation of human bone-derived cells in vitro. Bone 34, 112-123 (2004).

70. Basso, F. G., Turrioni, A. P. S., Hebling, J. \& De Souza Costa, C. A. Inhibition of osteoblast activity by zoledronic acid. J. Bras. Patol. e Med. Lab. 49, 368-371 (2013).

71. Vaisman, D. N., McCarthy, A. D. \& Cortizo, A. M. Bone-specific alkaline phosphatase activity is inhibited by bisphosphonates. Biol. Trace Elem. Res. 104, 131-140 (2005).

72. Gao, F., Liu, Y., Liu, M. \& Zhu, L. Zoledronic acid regulates osteoblast differentiation via the mTORC1 signaling pathway. 11, 4585-4594 (2018).

73. Yang, X. et al. Effects of graphene oxide and graphene oxide quantum dots on the osteogenic differentiation of stem cells from human exfoliated deciduous teeth. Artif. Cells, Nanomedicine Biotechnol. 47, 822-832 (2019).

74. Kang, E. S. et al. Size-dependent effects of graphene oxide on the osteogenesis of human adipose-derived mesenchymal stem cells. Colloids Surfaces B Biointerfaces 169, 20-29 (2018).

75. Lee, W. C. et al. Origin of Enhanced Stem Cell Growth and Differentiation on Graphene and Graphene Oxide. ACS Nano 5 , 7334-7341 (2011).

76. Bagri, A. et al. Structural evolution during the reduction of chemically derived graphene oxide. Nat. Chem. 2, 581-587 (2010).

77. Schech, A. J., Nemieboka, B. E. \& Brodie, A. H. Zoledronic acid inhibits aromatase activity and phosphorylation: Potential mechanism for additive zoledronic acid and letrozole drug interaction. J. Steroid Biochem. Mol. Biol. 132, 195-202 (2012).

78. Talukdar, Y., Rashkow, J. T., Lalwani, G., Kanakia, S. \& Sitharaman, B. The effects of graphene nanostructures on mesenchymal stem cells. Biomaterials 35, 4863-4877 (2014).

79. Rampersad, S. N. Multiple applications of alamar blue as an indicator of metabolic function and cellular health in cell viability bioassays. Sensors 12, 12347-12360 (2012).

80. Das Murtey, M. \& Ramasamy, P. in Modern Electron Microscopy in Physical and Life Sciences (ed. Janecek, M.) 161-183 (InTechOpen, 2016).

81. Brennan, M. Á., Renaud, A., Gamblin, A., Arros, C. D. \& Nedellec, S. 3D cell culture and osteogenic differentiation of human bone marrow stromal cells plated onto jet- sprayed or electrospun micro-fiber scaffolds $3 \mathrm{D}$ cell culture and osteogenic differentiation of human bone marrow stromal cells plated onto jet-sprayed or el. Biomed. Mater. 10, 1-13 (2015).

\section{Acknowledgements}

This work was supported by Boğaziçi University Research fund (No. 13601) and the Scientific and Technological Research Council of Turkey (TUBITAK) (No. 117M231).

\section{Author contributions}

Dr. Duygu Ege and Sepideh Tavakoli worked on the conception and design of the work. Sepideh Tavakoli and Gökçen Boran did the data collection. Dr. Duygu Ege, Sepideh Tavakoli and Gökçen Boran, Prof. Ingo Dierking and Ali Reza Kamali worked on data analysis and interpretation. Dr. Duygu Ege and Gökçen Boran worked on the drafting of the article. Dr. Duygu Ege, Prof. Ingo Dierking and Prof. Ali Reza Kamali did the critical revision of the article. All authors did the final approval of the version to be published. Best regards, Duygu Ege.

\section{Competing interests}

The authors declare no competing interests.

\section{Additional information}

Correspondence and requests for materials should be addressed to D.E. 
Reprints and permissions information is available at www.nature.com/reprints.

Publisher's note Springer Nature remains neutral with regard to jurisdictional claims in published maps and institutional affiliations.

(c) (i) Open Access This article is licensed under a Creative Commons Attribution 4.0 International License, which permits use, sharing, adaptation, distribution and reproduction in any medium or format, as long as you give appropriate credit to the original author(s) and the source, provide a link to the Creative Commons license, and indicate if changes were made. The images or other third party material in this article are included in the article's Creative Commons license, unless indicated otherwise in a credit line to the material. If material is not included in the article's Creative Commons license and your intended use is not permitted by statutory regulation or exceeds the permitted use, you will need to obtain permission directly from the copyright holder. To view a copy of this license, visit http://creativecommons.org/licenses/by/4.0/.

(C) The Author(s) 2020 